\author{
TANIA VANESSA ALVAREZ PORTUGAL \\ FACULTAD DE FILOSOFÍA Y LETRAS, UNAM
}

\title{
Bildwissenschaft. \\ Una disciplina en construcción
}

\begin{abstract}
7 ustav Frank y Barbara Lange presentan posturas y propuestas de diversos autores para el quehacer de una Bildwissenschaft o ciencia de la imagen en el libro Introducción a la Bildwissenschaft, imágenes en la cultura visual. ${ }^{\text {I }}$ Esta publicación se divide en los siguientes capítulos: "Introducción”; "Principios del sistema"; "Caminos de análisis", bajo el cual se agrupan: "Las imágenes en la práctica simbólica” y "Las imágenes en la práctica social”; "Conocimiento icónico" y una sección de "Análisis que parte de ejemplos concretos”. El libro presenta el estado actual de la Bildwissenschaft, su problemática y las principales reflexiones para el historiador contemporáneo. Éstas se establecen dentro del discurso historiográfico del arte, de donde inevitablemente surgen conceptos o presupuestos desarrollados en un determinado contexto y que a veces han probado ser limitados y conflictivos para el quehacer de una ciencia de la imagen. En la sección de "Análisis" se encuentran ejemplos del uso de la Bildwissenschaft en casos concretos de diferentes épocas, como el David de Miguel Ángel, las imágenes del conocimiento en modelo óptico de Kepler, la construcción visual de lo social en el retrato de María Antonieta, pintado por Élisabeth Vigée Le Brun, y en otros tantos ejemplos que le sirven al lector para comprender mejor la esfera de acción de la Bildwissenschaft. Esta publicación resulta una gran herramienta reflexiva y teórica en la medida en que articula teoría e investigaciones concretas. Es debido a su riqueza y a la utilidad que brinda a los estudios del arte, por lo que a continuación presento una síntesis teórica de lo más relevante.
\end{abstract}

I. (Darmstadt: WBG Wissenschaftliche Buchgesellschaft, 20го). 


\section{Introducción: la investigación de la imagen y de la cultura visual}

Los autores analizan la riqueza, más que el conflicto, resultante de la variedad de definiciones de imagen para el quehacer de la Bildwissenschaft, al ofrecer un breve, pero sustancioso recuento historiográfico de los estudios que se han ocupado en distintos niveles de la imagen, así como de su aspecto fenomenológico, semiótico, cultural o formal, los cuales en su conjunto conforman un antecedente de los estudios, compilaciones, artículos y propuestas generales de la Bildwissenschaft. De la introducción se desprende que el proyecto de ésta se aboca a investigar no sólo la imagen sino mucho más allá: la creación, difusión y prácticas de un conglomerado de artefactos visuales (como obras de arte, estructuras, mapas, telescopio y microscopio) en contextos histórico-culturales cambiantes, en prácticas sociales (las placas de experimentos neurocientíficos, la práctica museística, la extensión de la radio y la televisión) y en formas discursivas culturales (por ejemplo, la filosofía, la historia y la crítica del arte, las ciencias de las comunicación o las ciencias de los medios). Así, esta disciplina busca construir métodos interdisciplinarios para analizar e interpretar una cultura visual, a la vez que responde a una apremiante necesidad de estudios de la imagen, pues no existe ninguna disciplina que trate todos los tipos de imágenes, es decir, que se ocupe exclusivamente de las imágenes, de su percepción y efecto en la vida y sociedades humanas. Resulta evidente que en vista de los últimos avances tecnológicos en los medios visuales, impulsados por la sociedad contemporánea, y debido a la capacidad y necesidad de la ciencia y la técnica de producir y reproducir imágenes, son necesarios nuevos planteamientos teóricos con los cuales analizar los dispositivos productores, transmisores y receptores de las imágenes dentro de la cultura visual que los desarrolla.

\section{Imágenes en los medios y en las ciencias}

Este rubro inicia con una reflexión provocadora sobre la crítica de la imagen, su transmisión y percepción. Refiere cómo la novela de Las bellas imágenes (Les belles images) de Simone de Beauvoir, actualiza la tradición hostil a las imágenes, de Platón a Marx, pues en ella se considera que la imagen permanece al servicio de una apariencia sensible que aliena a la humanidad del conocimiento de la vida real. Sin embargo, al transmitir como radionovela Las bellas imágenes en la República Democrática Alemana, en 1973, fue posible establecer un vínculo con el concepto de evidentia procedente de la retórica antigua y ampliamente discutido 
por Marco Fabio Quintiliano en su Institutio Oratoria (ca. 95 d.C.). Mediante la evidentia se le presenta a los escuchas algo descrito vividamente, de tal modo que es posible hacer una imagen (pictura) mental que se puede "poner frente a los ojos". Esta actualización del uso del término permitió la profundización y el desarrollo de las reflexiones respecto a las imágenes contemporáneas.

De entrada la compilación aborda los nuevos retos que ofrecen las imágenes contemporáneas, como la formación de éstas mediante instrumentos de medición científica, los cuales hacen posible la visualización de resultados mediante las imágenes que producen. Es innegable el efecto que éstas tienen en el desarrollo del conocimiento y de la propia ciencia, puesto que posibilita que un determinado conocimiento específico pueda visualizarse de distintos modos. Los instrumentos de medición que generan imágenes de este tipo son por ejemplo los utilizados en los satélites para la observación espacial de la Tierra, mismos que registran mediciones sobre el cambio climático y la condición de los mares. Así, el medidor de temperatura, el radar de imágenes, el infrarrojo y el espectómetro por ejemplo, son recipientes de registros de variaciones de la radiación de la Tierra - todos los objetos y procesos de la Tierra y de la atmósfera lanzan, absorben o reflejan rayos electromagnéticos con diversas variaciones de onda y frecuencia. Los registros son torrentes de datos en códigos digitales que se convierten en números técnicos calibrados y luego se prueban en productos geofísicos. Se requiere reconstruir diversos programas que interpreten este torrente de datos y los transformen en formas visibles que sirvan de diagramas. Es así como registros tan amplios se vuelven visibles para el ojo humano en formas y colores, gracias solamente a una "traducción" realizada por instrumentos tecnológicos. Ante este fenómeno, el historiador de arte Horst Bredekamp ${ }^{2}$ y la historiadora de la ciencia y crítica de arte Julia Voss ${ }^{3}$ consideran que las imágenes funcionan no sólo como comunicación significante y medio de legitimación, sino también como instrumentos de conocimiento de alto grado en las comunidades modernas científicas y del saber, al volver visibles relaciones relevantes que en la base de datos no habrían sido calculadas. Así, la mirada ve más que las mediciones, el cálculo y su interpretación. Para el observador sin el conocimiento sobre el

2. Horst Bredekamp, Repräsentation und Bildmagie der Renaissance als Formproblem (Múnich: Carl Friedrich von Siemens-Stiftung, 1995); Bilder bewegen. Von der Kunstkammer zum Endspiel (Berlín: Wagenbach, 2007); Galilei der Künstler. Der Mond, die Sonne, die Hand (Berlín: Akademie, 2007).

3. Julia Voss, Darwins Bilder: Ansichten der Evolutionstheorie 1837-1874 (Fráncfort del Meno: Fischer Verlag, 2007). 
lugar, el tiempo, el acuerdo y la fijación de los caracteres sígnicos de los colores, la ilustración resultante de estos procesos de medición podría aparecer como un objeto estético, que no tiene referencia con un detalle de la realidad, sino sólo consigo mismo.

De esta forma, Frank y Lange explican que el proyecto de la Bildwissenschaft permite introducirse en la producción, extensión y uso de todos los tipos de artefactos visuales, para explorar, describir y reflexionar sobre su cambiante contexto histórico y cultural. En este sentido, la differentia specifica de la Bildwissenschaft descansa en que además de cuestionar la frontera entre las ciencias abre una discusión sobre la cooperación cultural de los instrumentos naturales y técnicos de percepción óptica, así como la representación humana y la técnico-instrumental de las imágenes. Martina Hessler, ${ }^{4}$ historiadora de la cultura y de la técnica, considera que la Bildwissenschaft se interesa no sólo en ampliar y definir los conceptos cambiantes de percepción, sino también en la vinculación con las respectivas prácticas de la representación de imágenes y de los principios de construcción de la visibilidad. A esto, una de las grandes autoridades en los estudios de la cultura visual, William John Thomas Mitchell, ${ }^{5}$ agrega como campos de exploración en el debate icónico los ámbitos no visuales de la cultura y los ámbitos no culturales de lo visual. De todo esto y de los esfuerzos realizados por los investigadores en sus respectivas disciplinas, se desprende que la ciencia, en su unión con la dimensión ideológica del orden simbólico, abre una puerta transdisciplinaria a los estudios de la Bildwissenschaft, sin dejar de lado la aproximación metódica necesaria.

\section{El proyecto de la Bildwissenschaft}

Desde la era moderna las sociedades occidentales han asentado constantemente nuevas redes de conocimiento sobre el mundo. El ensamblaje de ciencias que hoy se enseña en las universidades y los institutos de investigación no refleja una estructura dada del mundo, pues los estudios se enfocan en la individualización del objeto de estudio y en la especialización. El conocimiento del mundo es más

4. Martina Hessler, Konstruierte Sichtbarkeiten: Wissenschafts- und Technikbilder seit der Frühen Neuzeit (Múnich: Wilhelm Fink Verlag, 2006); Logik des Bildlichen. Zur Kritik der ikonischen Vernunft, eds. Martina Hessler y Dieter Mersch (Bielefeld: Transcript, 2009).

5. William John Thomas Mitchell, Picture Theory: Essays on Verbal and Visual Representation (University of Chicago Press, 1994); What do Pictures Want? The Lives and Loves of Images (University of Chicago Press, 2005). 
bien el resultado de complejas interacciones sociales que han conducido a desplazamientos constantes de los intereses de conocimiento. ¿Cómo se posiciona la Bildwissenschaft ante este escenario? Todavía hasta 2010 no podía aseverarse que hubiera cumplido con todos los criterios necesarios para considerarse como una ciencia completamente válida y autónoma, sin embargo, ha generado un creciente número exponencial y cambiante de publicaciones, entre ensayos y volúmenes, monografías e introducciones, así como estudios curriculares y especializaciones de investigación. A pesar de todo esto, no existe hasta el momento ninguna universidad correspondiente o instituto de investigación que garantice su asentamiento. Esta situación permea no solamente el ámbito institucional, sino todo el proyecto de manera determinante, pues la Bildwissenschaft obtiene de esta situación una gran diversidad que no hubiera sido posible adquirir con una teoría, un método y temas fijos.

Ante este escenario, los autores, después de exponer sumariamente la historia de los Visual Culture Studies angloamericanos — sus líneas de exploración y desarrollo-, sugieren, sin embargo, que la Bildwissenschaft debe ser más que una secuencia jerárquica o suma de las disciplinas individuales, pues las discusiones altamente controvertidas en la investigación de la imagen señalan que éstas requieren de su propia especialización. A pesar de que hasta el momento existen muchas posturas encontradas sobre el concepto de imagen, el hecho de estos intentos en centrar el énfasis en la amplia diferenciación de los conceptos que obtiene la imagen de sus diversas prácticas culturales es resultado del interés por introducir una autoridad científica para regular una práctica social. No obstante, los autores pugnan por utilizar esta práctica misma como una base para esbozar las dificultades que se presentan en los conceptos de la imagen y hacerlos así fructíferos. Frank y Lange parten de este hecho y puntualizan que los alcances del texto no pretenden entonces delimitar los amplios estudios existentes de la Bildwissenschaft o introducir al lector en ellos, sino que buscan desafiar la curiosidad por los fenómenos de la cultura visual, tomando en cuenta el papel de la ciencia en la situación actual.

De esta manera bajo el concepto de Bildwissenschaft se sigue la denominación empleada para todas las actividades de investigación sobre la cultura visual en el ámbito alemán. Los autores señalan que una traducción del término a otros idiomas resultaría inutilizable, como por ejemplo image science en el mundo de la investigación global. Lo mismo sucede con la médiologie propuesta por Régis Debray, ${ }^{6}$

6. Véase Régis Debray, Le pouvoir intellectuel en France (París: Ramsay, 1979). 
o el programa de investigación angloamericano — con James Elkins, Mirzoeff y Evans - caracterizado como Visual Cultural Studies, 7 pues, aunque el estudio de la imagen resulta una necesidad internacional, las diferencias programáticas muestran que apenas ha existido una recepción e intercambio mutuos entre las distintas tradiciones lingüísticas. De tal forma, como ejemplo, la lengua alemana no encontró en el pictorial turn de w.J.T. Mitchell un equivalente de contenido con el iconic turn de Gottfried Boehm. Así, dicha Introducción busca ser una guía para los primeros escritos profesionales en la cultura visual y por ello presenta los puntos más sobresalientes de los conceptos, modelos y argumentos propuestos, para volver a abrir la programática en los debates. Los ejemplos de análisis al final del libro se eligieron de tal modo que diversos temas y facetas deben estimular la curiosidad y abrir incluso nuevos usos y campos de investigación.

\section{Campo de investigación de la cultura visual}

A pesar de que en el ámbito de habla alemana la historia del arte se consolidó desde el siglo XIX como lo que entendemos hoy día por ciencia moderna, las raíces de una historiografía del arte, que se sirvió del juicio artístico como referencia para la producción y valorización de artefactos, datan desde la Antigüedad hasta la modernidad. Desde principios del siglo Xv en Italia, sobre todo en Florencia, el desarrollo de una "autoconfianza" en el arte, a decir de Victor Stoichita, fue reflejo de una emancipación creciente del contexto de la simple manufactura, lo cual le permitió a la creación artística reflexionar sobre sus posibilidades de creación. Esto condujo a la formación de un sistema historiográfico de percepción y de formación críticos. Este sistema, con todas las implicaciones ideológicas que pueda tener, es la base de la práctica moderna de la historia del arte, y no habría de olvidarse que también condicionó la formación de diferentes escuelas.

El mismo concepto del arte, cuya propia historicidad lo revela como una categoría característica de una "cultura de elite", fue conducido fuera del vasto campo de la cultura visual. Además los autores son de la opinión de que, a pesar de la fuerte unión con la Antigüedad, la historia del arte inició su delimitación del área de objeto de estudio con la era del cristianismo, por lo que se encuentra condicionada a una historia del arte eurocéntrica, reflejada hasta hoy día en su nomenclatura. Finalmente la reflexión de este déficit ha conducido a que el historiador del arte, junto con su instrumentario analítico, adquiera un importante 
y valioso conocimiento sobre las formas de la imagen y su historia, así como sobre los medios y la historia material de las imágenes.

En este sentido para la Bildwissenschaft los conceptos del cuerpo desempeñan un papel constitutivo como campo de investigación. Uno de sus cimientos, presentado como la "antropología de la imagen" en los estudios de Hans Belting, hace del cuerpo humano el punto de referencia y medida de la percepción y representación de la imagen. ${ }^{8}$ Los cuerpos aparecen en esta perspectiva no sólo como tema de formación visual sino como portadores de imágenes (la piel tatuada), a la vez que una interfaz entre percepciones ópticas del mundo y expresiones visuales de la psique, las cuales existen como imaginaciones mentales. Ya a principios del siglo xx el académico independiente, Aby Warburg, centró su atención en las figuras del lenguaje corporal (gestualidad) en la pintura del Renacimiento que imitaba las formas antiguas, y detectó que a las imágenes les eran inherentes funciones mnémicas perdurables vinculadas con la transmisión de dichas formas. Para la Bildwissenschaft esta tesis resulta central en la búsqueda de factores atemporales de la iconicidad (Bildlichkeit), porque, a decir de Horst Bredekamp, "la memoria en su función mnémica no se interesa por los portadores de imágenes ni jerarquías, ni por géneros ni causas. La memoria registra las formas comparables y la energía de las emociones que provocan". ${ }^{9}$

Más que la búsqueda por constantes antropológicas, se fomenta un interés por los diferentes planteamientos formulados y que ayudan a reconstruir la amplia gama de visualización de conceptos corporales no sólo en las artes plásticas, sino también en el teatro y la danza, en los medios electrónicos, así como en la concepción de modelos artísticos y culturales como lo realiza Barbara Lange. ${ }^{\text {Io }}$ También para Fischer-Lichte este tipo de aproximaciones despiertan preguntas sobre el cuerpo en movimiento en escena actualizando así la investigación del performance; asimismo estos planteamientos se emplean en consideraciones fundamentales de la percepción como acto corporal, tratado ampliamente por Sybille Krämer. ${ }^{\text {II }}$

8. Véase Hans Belting, Antropología de la imagen, trad. Gonzalo María Vélez Espinoza (Madrid: Katz, 2007).

9. Horst Bredekamp, Bilder bewegen. Von der Kunstkammer sin versalitas zum Endspiel. Aufsätze und Reden, ed. Jörg Probst (Berlín: Wagenbach, 2007), I79 (trad. de la autora).

Io. Véase Barbara Lange, Visualisierte Körperkonzepte: Strategien in der Kunst der Moderne (Berlín: Reimer, 2007).

I I. Véase Sybille Krämer, Performativität und Medialität (Múnich: Wilhelm Fink, 2004). 
Asimismo, otro ámbito de estudio de la Bildwissenschaft es la ciencia de los medios que ordena las imágenes en un lugar preciso dentro de un elaborado sistema de teoría y conocimiento. Ésta comprende principalmente a las imágenes en los medios modernos masivos de la sociedad occidental. Hacia principios del siglo $\mathrm{xx}$ se requirió de la integración y competencia de medios e imágenes, y para ello se emplearon consideraciones teóricas apropiadas de asombrosa actualidad, como por ejemplo, los planteamientos de Moholy-Nagy de 1986. ${ }^{\mathrm{I2}}$ Hoy cuenta la ciencia de los medios con herramientas de las ciencias sociales que brindan la posibilidad de realizar una investigación cuantificada sobre la utilización de los medios, a saber, cómo cuentan y se miden las imágenes. Dentro de la ciencia de los medios existe una pronunciada rama orientada a la técnica que explora el sistema de grabaciones de video, de transmisiones, y de reproducción como a priori de la comunicación, independientemente del contenido, como se propone en Friedrich Kittler. ${ }^{13}$ Sin embargo, a decir de Rieger, los medios procesan los datos, el mundo o el conocimiento mediante una terminología inoperativa, utilizando conceptos como "representación" o "mímesis", mientras que en la nueva terminología y, bajo el requisito de que estamos ante una virtualización ubicua, los datos se tratan como una simulación. Algunos de estos puntos de vista sobre los medios anclan sus conceptos en la historia del arte y en la filosofía de los medios, poniendo la concepción del sujeto actuante en duda, lo que ocasiona algunos problemas debido, principalmente, a la utilización de conceptos caducos. Es así que para Frank y Lange, por ejemplo, el intento de Klaus Sachs-Hombach, desde el lado filosófico, por describir la imagen como medio comunicativo resulta tradicional al interesarse en una interpretación de las imágenes como "signos perceptualmente cercanos" tanto en las funciones de referencia con la realidad y con la percepción, como en la construcción de significado y el uso de la situación pragmática. ${ }^{14}$ Conceptos como medio y cuerpo en este tipo de enfoques no cobran una relevancia significativa, ni tampoco el propio concepto de la imagen y por tanto no funcionan como fundamento estable que pueda emplearse en la Bildwissenschaft.

Otra perspectiva que ha enriquecido el debate en la Bildwissenschaft es la fenomenología de la imagen. En esta corriente se retoman principalmente los

I2. Véase Krisztina Passuth, Moholy-Nagy (Weingarten: Kunstverlag Weingarten, 1986).

13. Friedrich Kittler, Optische Medien (Berlín: Berliner Vorlesung, 1999).

I4. Klaus Sachs-Hombach, Das Bild als Kommunikatives Medium. Elemente einer allgemeinen Bildwissenschaft (Colonia: Halem, 2003). 
escritos de Maurice Merleau-Ponty, a partir de los que la imagen, casi exclusivamente la obra de arte, se observa y concibe como objeto independiente. Aquí se discute en primera instancia sobre la percepción. Esta posición se sustenta por aquellos que argumentan con una formación avenida de la historia del arte o la filosofía. Otros, al emplear una estructura analítica, consideran posible una lectura de las imágenes como una acumulación recurrente y múltiple de signos, y, apoyándose en Walter Benjamin, articulan la necesidad de recuperar la comunicación de la pintura con la palabra hablada y la escrita. De tal modo se cuenta con el concepto de "iconotexto" de Peter Wagner, el cual procede de una interdependencia fundamental entre pensamiento visual y percepción textual. ${ }^{\text {Is }}$

Frank y Lange aclaran que la Bildwissenschaft va más allá de esa controversia de la dimensión imaginativa que agrupa a la lengua y a la imagen, y por ejemplo dirigen también su atención a las cualidades de las imágenes dentro de los sistemas de notación. Resulta así que la visibilidad de los textos en metáforas textuales poetológicas, así como la notación musical y los movimientos del cuerpo en un cuarto son temas a tratar en la Bildwissenschaft.

El hecho de que constantemente se ponga en duda la relación entre imagen y signo, se debe al no menos importante gesto hegemónico de las ciencias centradas en el signo y el texto, pues éstas han pugnado por concebir la cultura entera como "texto" y con ello han intentado leerla de manera cognitiva y logocéntrica. ${ }^{16}$ No obstante, es preciso tomar en cuenta que la semiótica es un acercamiento heterogéneo que, no en el sentido del linguistic turn, describe todas las expresiones culturales en analogía con la lengua natural, al aproximarse a las imágenes no sólo de manera abstracta y sistemática, sino también de forma concreta. Este planteamiento es utilizado por Oliver Scholz para describir las partes del proceso sígnico en el arte y en la imagen. ${ }^{77} \mathrm{~A}$ la Bildwissenschaft le resultan útiles los instrumentos semióticos siempre y cuando permitan analizar los artefactos visuales en su generación de sentido más allá de su reducción a fungir sólo como medios de comunicación, y son bienvenidos cuando ayuden a superar la fijación de los sistemas de comunicación y del arte.

I5. Véase Peter Wagner, Icons, Texts, Iconotexts: Essays on Ekphrasis and Intermediality (Berlín y Nueva York: W. De Gruyter, I996).

16. Kultur als Text. Die anthropologische Wende in der Literaturwissenschaft, eds. Doris Bachmann-Medick, James Clifford (Fráncfort del Meno: Fischer, 1996).

I7. Véase Oliver Scholz, Bild, Darstellung, Zeichen (Fráncfort del Meno: Vittorio Klostermann, 2004). 
La Bildwissenschaft, junto con la neurología, se esfuerza por establecer un tercer pilar para lograr una novedosa aproximación a las imágenes producidas por el cuerpo mediante la tecnología. En este rubro, la investigación cerebral brinda un futuro sobre el conocimiento de las sucesiones neuronales de las percepciones ópticas. Aunque estos medidores y las imágenes que se originan de estas mediciones, están sujetas a la transformación cultural y muestran una gran proximidad con otras formaciones de imágenes de su tiempo; buscan dar explicaciones sobre la producción mental icónica a pesar de su anclaje en sistemas de conocimiento marcados culturalmente y además proporcionan información sobre las dimensiones transculturales y biológicas de la definición de imagen. Se destaca en este punto la investigación del fisiólogo Hermann von Helmholtz, cuyos resultados en el siglo XIx no obtuvieron lamentablemente una recepción significativa en el terreno del arte y conocimiento cultural. ${ }^{18}$ Más allá aún, la creciente especialización de las disciplinas hoy día, ha dificultado un encuentro entre el arte, la ciencia de los medios y la neurofisiología. Sin embargo, al optar por un plano común que las reúna, como sucede en la Bildwissenschaft, donde el empirismo, la historia cultural y la crítica ideológica se unen a la crítica histórica de la imagen, se abren oportunidades de acercamientos fructíferos, pues es factible reunir todos los intereses de investigación de cada disciplina específica en la medida en que cuentan con un tema en común: las imágenes y su percepción.

Sin embargo, si bien la Bildwissenschaft comparte su objeto de estudio con otras disciplinas, para Frank y Lange, su tema genuino y por excelencia son las imágenes. Por tanto se interesan por la particularidad que distingue a la imagen con respecto de otras materias. En este sentido resulta de suma importancia la aportación de la pregunta formulada por el historiador de arte y filósofo Gottfried Boehm desde los años noventa y desarrollada a lo largo de sus escritos: ¿cómo mediante la percepción de la imagen y sus condiciones se lleva a cabo una generación de sentido visual? ${ }^{19}$ A este respecto la Bildwissenschaft debe dominar la paradoja de que su objeto de estudio es diferente del lenguaje verbal, pero que a la vez debe articularlo mediante el lenguaje. Una solución a esta contradicción consistiría en que, como lo manejan Christian Emden y Gabriele Rippl,

I8. Véase Hermann von Helmholtz, Handbuch der physiologischen Optik (Leipzig: Leopold Voss, I867).

19. Gottfried Boehm, Wie Bilder Sinn erzeugen. Die Macht des Zeigens (Berlín: Berlin University Press, 2007). 
aquello inherente a las imágenes que se presenta como intransferible mediante una traducción intermedial — como el lenguaje verbal — sea susceptible de describirse en un metanivel. ${ }^{20}$ Esto se puede intentar mediante la construcción de un observador (histórico) en una situación específica "ante la imagen". ${ }^{21}$ Para ello es necesario interrogar qué tan comprensibles resultan para la aprehensión humana la forma y la figura, cómo se construye el lugar de presentación y su accesibilidad, cómo funciona la perceptibilidad y cuál es su posición en el mundo afectivo. En este tenor, dentro del orden social preguntarse, asimismo, por el lugar que ocupa la percepción de las mujeres y de los hombres; si es una posición idéntica o equiparable. Aunado a esto, considerar qué es susceptible de fungir como una disposición atemporal y qué se encuentra fundado culturalmente. La teoría general de los sistemas ha señalado como deficiencia la incomprensión del sistema psíquico y la invisibilidad de las operaciones emocionales. Lo que se percibe es primeramente una comunicación que, al recurrir siempre a las fuentes escritas, se sujeta a reglas que deben analizarse críticamente. De ahí que sea necesario formular mayores preguntas acerca del uso, por ejemplo, como consumo y demanda, o como inversión en distinción social; ${ }^{22}$ así como también de acuerdo con el papel que desempeñan los instrumentos ópticos como el microscopio, el telescopio, la cámara oscura, los equipos generadores —y reproductores- de imágenes, como el estereoscopio, la cámara fotográfica, la cámara de video y el proyector de la computadora. Finalmente se trata grosso modo de un análisis sobre la pregunta lanzada por el filósofo Dieter Mersch: ¿en qué medida la medialidad y la materialidad de la imagen estimulan productivamente la imaginación del observador? Al compararlo con una comunicación cerrada, donde la imagen funge sólo como un signo previamente fijado, los resultados que se pueden obtener son por lo demás fructíferos para el debate en torno al papel desempeñado por las imágenes en nuestro vivir cotidiano. ${ }^{23}$

20. Christian Emden y Gabriele Rippl, The Irreductibility of Images: Intermediality in Contemporary Literary and Cultural Studies (Óxford: Peter Lang, 2005).

21. Véase Georges Didi-Huberman, La Ressemblance informe, ou Le gai savoir visuel selon Georges Bataille (París: Macula, 1995); Vor einem Bild (Múnich: Carl Hanser Verlag, 2000).

22. Véase Pierre Bourdieu, Zur Soziologie der symbolischen Formen (Fráncfort del Meno: Suhrkamp, 1970); Die feinen Unterschiede. Kritik der gesellschaftlichen Urteilskraft (Fráncfort del Meno: Suhrkamp, I982).

23. Véase Dieter Mersch, "Bild und Blick. Zur Medialität des Visuellen," en Media Synaesthetics, Konturen einer physiologischen Medienästhetik, eds. Christian Filk, Michael Lommel et al. (Colonia: Halem, 2004), 95-I22. 


\section{Principios del sistema}

En este segundo capítulo, Frank y Lange ponen sobre la mesa la diferenciación y división de las imágenes que han desarrollado algunos autores con la finalidad de lograr una aproximación teórica a ellas. Para ello inician exponiendo cómo la historia del arte, como una disciplina con método científico, se ha ocupado de la imagen, en tanto que desarrolla una instrumentación para su descripción, clasificación e interpretación. Es así cómo metodológicamente se ha podido analizar tanto la facultad como la estructura de la imagen y sus efectos en la sociedad.

En este sentido, para los autores, uno de los libros capitales — para la Bildwissenschaft en el área de lengua alemana-, fue la compilación de Boehm que reunió respuestas diferentes a la pregunta esencial de qué es una imagen retomando posiciones de la fenomenología planteadas a partir de las reflexiones de Edmund Husserl. En este sentido la imagen es en cuanto se muestra. ${ }^{24}$ Sobre esta línea desarrolla Gernot Böhme su planteamiento de que la imagen no siempre es una representación figurativa de algo, sino que también puede ser por sí misma, como constata mediante un acucioso análisis de la Mona Lisa de Leonardo da Vinci. Con ello se opone a la antigua teoría del signo para la cual una imagen sin referencia no puede ser definida como una imagen, según se entiende a partir de la semiótica de Umberto Eco. A pesar de que estas posiciones se confrontan y oponen entre sí, es preciso reconocer que tienen en común el desarrollo de sus argumentos a partir de las obras de arte.

La historia del arte no sólo produce acercamientos metodológicos útiles que tienen por objeto descripciones formales y análisis de imágenes, sino que también dispone de perspectivas analíticas que nos dan cuenta del lugar social que ocupan las imágenes, y, por tanto, su integración en contextos y prácticas sociales. Con ello la disciplina reflexiona actualmente sobre sus condiciones propias y ha demostrado que el fenómeno de clasificar la obra pictórica como arte, es hasta cierto punto joven históricamente y, al mismo tiempo, resultado de convenciones sociales. Este fenómeno inicia en círculos de formación humanista, en el medioevo tardío en Italia, mediante una lenta emancipación de los artesanos que fabricaban figuras de diversos materiales (piedra, madera, metal) susceptibles de ser transportadas en soportes móviles y cuyo diseño y medialidad fueron reconocidos y valorados por sus peculiaridades en un ambiente de círculos humanistas que, al compararlas con las obras de la Antigüedad, establecían un vínculo entre

\footnotetext{
24. Boehm, Wic Bilder Sinn erzeugen, 28-32.
} 
el potencial afectivo surgido de dichas peculiaridades con la tradición retórica clásica de afectación. Este proceso se consolida con la institucionalización del arte, a saber, la creación de una propia instancia para la discusión y valoración de estos artefactos. Bajo ella se pueden considerar el mecenazgo (como por ejemplo el patrocinio de la familia Médici) y el establecimiento de centros de formación independientes de los artesanos - la primera academia estatal se inauguraría en Francia en 1648-; así como el surgimiento de la teoría y la crítica de arte, el coleccionismo y las exposiciones.

Este complejo proceso desarrollado en la época moderna, integró de manera retrospectiva objetos e imágenes producidos durante el medievo en su canon de "arte", pero que no habían sido en principio concebidas bajo dichos fines. La historia del arte ante este fenómeno y con vista al pasado, plantea preguntas sobre el proceso de diferenciación entre "arte" y las otras imágenes, aquellas relacionadas evidentemente con mecanismos de acción específicos de la imagen. A decir verdad lo que se había negociado como arte al comienzo fue también utilizado como un medio de distinción, con el que los coleccionistas y mecenas podían caracterizarse como una elite que en la sociedad del temprano capitalismo de la Holanda del siglo xvir, ya contaba con una amplia base.

\section{Las obras de arte en la historia}

La misma historia del arte permite registrar cómo la producción de imágenes y la recepción de éstas se condicionan mutuamente mediante negociaciones establecidas, a la vez que es capaz de describir también el proceso en su consolidación histórica. Sin embargo, la postura de la Bildwissenschaft no puede permanecer sólo relacionada con el arte. Para ello es necesario ubicar primero un concepto no jerárquico de la imagen, para después emprender una teorización de las diversas imágenes de todos los tiempos, culturas y técnicas de un modo más justo. Para tal fin puede considerarse como punto de partida el análisis de la visualidad como ha sido propuesto por Mitchell, y que puede entenderse como un entrelazamiento de las condiciones corporales del ser humano y su medio ambiente. Por otra parte, del lado alemán, como lo ha desarrollado la filósofa e historiadora Eva Schürmann, se entiende que en efecto la vista es una práctica performativa que se involucra en una interacción entre significaciones y normas. ${ }^{25}$ Precisamente los procesos histó-

25. Eva Schürmann, Sehen als Praxis, Ethisch-ästhetische Studien zum Verhältnis von Sicht und Einsicht (Fráncfort del Meno: Suhrkamp, 2008). 


\section{8}

TANIA VANESSA ALVAREZ PORTUGAL

ricos que se vinculan con los procesos de generación artística y que condicionan cambios en las culturas visuales proporcionan información valiosa para las discusiones sobre la imagen en sí, así como en lo que respecta a su definición.

\section{El uso de las imágenes}

En este apartado se profundiza sobre el quehacer de la Bildwissenschaft en su diferencia frente a la historia del arte, tomando como base el hecho de que las imágenes hacen visibles contenidos complejos y muestran además algo que mediante ellas desaparece y es sustituido simultáneamente. Por tanto son imágenes no sólo las relativas al "arte". Mientras la historia del arte se interesa por definir cuáles imágenes son arte dependiendo de las condiciones histórico-sociales cambiantes, la Bildwissenschaft no centra su atención en dicho interés y consecuentemente para ella todo tipo de imágenes son objeto de estudio.

Ante este panorama, la frontera entre arte e imágenes no artísticas debe negociarse y asumirse constantemente a un nivel donde se tomen en cuenta las diferentes prácticas y proyecciones culturales inscritas en prácticas icónico-visuales más allá del continente europeo. En este sentido se dan ejemplos de artefactos (fetiches) utilizados en rituales mágicos procedentes de otros continentes, a partir de los cuales es posible derivar bases conceptuales analíticas que arrojen luz sobre los aspectos psicoanalíticos que se dan en contacto con las imágenes. Para explicar lo anterior, resultan medulares los estudios de Fritz Kramer, quien explica cómo el fenómeno del fetiche del oeste de África sirvió como modelo en la búsqueda de formas básicas de arte. ${ }^{26}$

Siguiendo la reflexiones anteriores, Frank y Lange refieren que las imágenes se codifican siempre culturalmente, aunque también es necesario tomar en cuenta la inmediata percepción sensorial humana ante las imágenes: el nervio óptico registra con diferente intensidad los colores, el sentido del tacto genera la representación de una imagen mediante la experiencia con la materialidad visible. Gracias a nuestras experiencias cotidianas imaginamos lo cercano, si algo es suave o áspero, si se siente cálido o frío, o si es suave o duro. Los aromas desprendidos de un color fresco o de determinada materialidad contribuyen a la estructuración de nuestra percepción. La consideración de estos aspectos conlle-

26. Fritz Kramer, "Praktiken der Imagination," en Die Unvermeidlichkeit der Bilder, ed. Gerhard von Graevenitz, Stefan Rieger et al. (Tubinga: Narr, 200I), I7-30. 
va a considerar la cuestión de la orientación en el espacio ampliamente abordada por los autores del libro. Veamos el porqué.

\section{Orientación: el espacio visible}

El espacio se fundamenta en nuestras percepciones corporales inmediatas: el ser humano responde a la altura, a la amplitud, al vacío, entre otros, y así determina la atmósfera de la situación de un lugar. A diferencia del concepto de espacio abstracto, de la geometría de Euclides o de la filosofía trascendental de Kant, Michel de Certeau formula que existe la experiencia de espacio en relación directa con la situación corporal, precisamente lo que se experimenta también en la confrontación con las obras plásticas o las esculturas. ${ }^{27}$ En este sentido cabe valorar escenificaciones en la arquitectura urbana y el diseño de espacios interiores donde se configuran zonas que modifican la experiencia espacial. Otro aspecto digno de destacar por los autores es la adaptación del espacio a reglas sociales, como lo manifiesta la disposición, el registro y la producción del espacio. A colación, Frank y Lange mencionan la postura teórica sociológica de Martina Löw quien postula el concepto de spacing, entendiéndolo como "ponerse en lugar" y esta acción implica procesos simultáneos donde el individuo se relaciona tanto con otras personas como consigo mismo y con las cosas, de manera que la realidad resulta ser una verdadera construcción. Este intercambio de relaciones produce imágenes del espacio que dependen de la necesidad inmediata de la percepción sensorial, siempre localizada en el aquí y en el ahora. Dichas imágenes hacen referencia a las tradiciones y su significado simbólico, generado mediante la superposición o estratificación del saber cultural. En síntesis, el "adquirir conocimiento" del espacio es una técnica cultural que ancla sus bases en la creación formal de imágenes-espacio. ${ }^{28}$

Ciertamente la transmisión de las imágenes construidas bajo las leyes de una perspectiva central operan inevitablemente con la fijación permanente de un punto de vista e implícitamente con un cuerpo fijo, mientras que en la realidad el ser humano genera activamente el espacio mediante el movimiento, en relación con la experiencia total de su cuerpo. La perspectiva central reduce la

27. Véase Michel de Certeau, La invención de lo cotidiano I, Artes de hacer, trad. Alejandro Pescador (México: Universidad Iberoamericana/Instituto Tecnológico de Estudios Superiores de Occidente, 2000).

28. Martina Löw, Raumsoziologie (Fráncfort del Meno: Suhrkamp, 200I). 
percepción del espacio a la óptica, mientras que en la vida real todos los sentidos activos contribuyen a la capacidad de orientación de nuestro cuerpo. Una camera silens, como por ejemplo en la instalación de James Turrell, resulta una forma de arte porque el spacing y la "capacidad de síntesis" complementan la experiencia espacial en la vida real. Frank y Lange sugieren que una Bildwissenschaft, considerada como crítica, debe tomar en cuenta las diferencias culturales reflejadas en ideologías y, por tanto, en perspectivas, lo cual la conllevaría a realizar una amplia y profunda investigación sobre la construcción de la perspectiva y con ello contribuir a la concientización de la imagen a lo largo de los siglos.

\section{El movimiento visual}

El cineasta Béla Balázs refiere que desde 1924 se dio por primera vez un discurso sistemático sobre la cultura visual en el momento en el que el cine mudo alcanzó un punto climático en la historia. Trabajos como el Bronenosec Ptjomkin (El acorazado Potemkin) de Sérguei Eisenstein (URss 1925) o Der letzte Mann (El último hombre o La última carcajada) de Friedrich Wilhem Murnaus (Alemania 1924) desarrollaron su medio de tal forma que se discutió más allá de ser un simple producto de esa industria del entretenimiento: se planteó como forma de arte independiente. ${ }^{29}$ Sobre los procedimientos fílmicos que hicieron esto posible, es notable el trabajo de movimientos independientes en el espacio realizados por camarógrafos, así como el montaje en la edición final de las películas, elementos que lograron atraer mayor atención porque abrían posibilidades irrealizables en el teatro.

Este desarrollo se acompañó por discusiones fundamentales sobre la teorización de las imágenes hacia la cual se inclinó la cinematografía en su esperanza de ser herramienta de transformación de la cultura y de la sociedad. En este sentido Balázs dirigió sus esfuerzos hacia una reforma social a favor de una revisualización de la cultura, desde la ejecución de la película hasta el cine. También Walter Benjamin seleccionó la película como punto de fuga en su historia de las técnicas de reproducción del cine. ${ }^{30}$ Así, puesto que con el celuloide fílmico se introdujo el interés en el estudio del movimiento humano, se revaloró todo un complejo de cultura visual más que la imagen aislada como objeto de estudio.

29. Véase Béla Balázs, Der sichtbare Mensch oder die Kultur des Films (Fráncfort del Meno: Suhrkamp, 2004).

30. Véase Walter Benjamin, Discursos interrumpidos, trad. J. Aguirre (Madrid: Taurus, 1973). 


\section{El movimiento visual}

Ante este escenario, los autores consideran que las experiencias con dicho medio y el interés por la exploración de la cultura visual dependen uno del otro y ambos descansan sobre los mismos requisitos sociales de pensamiento y de mentalidad históricos. Así, ya para I920 el cinematógrafo y sus proyecciones pudieron desencadenar una nueva reflexión sobre el significado de la visibilidad, pues en este medio la modernidad urbana se reflejaba como en un espejo y podía investigarse a sí misma. El espejo no fue sólo una metáfora, sino que se destacó visiblemente y se puso en escena con el asfalto de las calles de películas alemanas urbanas como Die Strasse de Karl Grune (1923), o en los reflejos en los escaparates presentes en Eine Stadt sucht einen Mörder de Fritz Lang (193I) o bien en City Lights de Charlie Chaplin (I93I). Estos reflejos cobran un papel central en la medida en que juegan con las superficies visibles, con la materialidad y con la transformación dinámica de la ciudad así como del medio.

Según la propuesta de Jonathan Crary, el tiempo y el movimiento podían verse y experimentarse, pero no podrían reproducirse en su totalidad, antes de la incursión del cine. ${ }^{3 \mathrm{I}} \mathrm{La}$ ilusión que produce mediante procesos de movimiento generados gracias a la alineación de fotografías en serie dispuestas en un rollo y de su rápida proyección, abre un punto específico en la historia del cine. El cine rescata el vínculo entre la representación del movimiento y el ilusionismo que ya desde el siglo XviII se perfilaba como norma en la educación, al revalorar la naturaleza mediante los sentidos y convertir así la experiencia del mundo empírico en medida de representación. Esto conllevó al surgimiento de la aisthesis como disciplina filosófica ocupada en la percepción sensorial a la cual pertenecería también el arte. Según Frank y Lange, fue la revaloración de la naturaleza sensorial la que la liberó también de una representación sometida a la visualización de ideas y conceptos tradicionales, y de tal forma adquirió tanto prestigio que se llegó a pensar en una autonomía del arte, cuyo debate estético, a decir de Winckelmann, sería llevado a cabo por medio de ejemplos de la antigua plástica griega. ${ }^{32}$

3I. Véase Jonathan Crary, Las técnicas del observador: visión y modernidad en el siglo XIX, trad. Fernando López García (Murcia: Centro de Documentación Estudios Avanzados de Arte Contemporáneo, 2008).

32. Johann Joachim Winckelmann, Reflexiones sobre la imitación del arte griego en la pintura y la escultura, trad. Vicente Jarque (Barcelona: Península, 1987). 
Dentro de este breve recorrido histórico, los autores nos recuerdan que para el último tercio del siglo XIX se retomó el interés por la visibilidad y las representaciones visuales del movimiento, lo que dio pie a iniciar una crítica de la cultura como crítica de la lengua, a la que se le percibió entonces como la forma de fosilización de la vida en convenciones sociales e intelectuales. Este planteamiento guió a la postura compartida por Ellen W. Goellner y Jacqueline Shea Murphy, de preferir la danza y otras artes acrobáticas y circenses, es decir, todo aquello que se ejecuta como "ejercicio mudo". ${ }^{33}$ Se caracterizan como mudas porque no pueden fijarse lingüísticamente: no poseen códigos de movimiento como sucede en las secuencias de pasos seguidos por la danse d'école. ${ }^{34}$ A decir de Mallarmé, estos ejercicios mudos son acontecimientos no convencionales y efímeros del movimiento. Como écriture corporelle ${ }^{35}$ pueden también vincularse con una nueva lengua poética no convencional cuya escritura misma puede entenderse como una forma de danza de palabras que busquen finalmente formar sus propias letras mediante secuencias de movimiento. Junto con este planteamiento surgen otras preguntas que delinean nuevos campos de exploración como las formas de grabación del movimiento.

La grabación del movimiento mediante la fotografía en serie, junto con estudios sobre la fisiología de los ojos y sobre la psicología de la vista, fundan las bases para la ilusión de movimiento mediante la circulación suficientemente rápida de la propia serie de imágenes que proyecta el cinematógrafo. Hasta la década de 1930 la discusión teórica del cine gira en torno a la percepción y a la sensación de movimiento que genera él mismo. Esta discusión sobre la grabación medial del ser humano en movimiento y cuyo comportamiento expresivo se hace visible en la pathosformel — término forjado por Aby Warburg- ${ }^{36} \mathrm{o}$ bien en la patología de los "hombres visibles" — término de Balázs—, así como en la cultura visual de los fenómenos urbanos trabajados por Siegfried Kracauer, ${ }^{37}$

33. Ellen W. Goellner y Jacqueline Shea Murphy, Bodies of the Text: Dance as Theory, Literature as Dance (Nueva Jersey: Rutgers University Press, 1995).

34. Guy Ducrey, Corps et graphies. Poétique de la danse et de la danseuse à la fin du XIXe siècle (París: H. Champion, 1996).

35. Euvres complètes de Mallarmé, ed. Bertrand Marchal, 2 vols. (París: Gallimard, I9982003).

36. Véase Aby Warburg, Der Bilderatlas Mnemosyne, eds. Martin Warnke y Claudia Brink (Berlín: Akademie Verlag, 200o); Aby Warburg. El atlas de imágenes Mnemosine, ed., trad. y notas, Linda Báez (México: Universidad Nacional Autónoma de México-Instituto de Investigaciones Estéticas, 2012).

37. Véase Siegfried Kracauer, Construcciones y perspectivas: el ornamento de la masa, trad. 
y las técnicas de reproducción tratadas por Benjamin, son ideas y propuestas con gran potencial de desarrollo teórico-metodológico que continuamente son retomadas como puntos de partida por la ciencia de las imágenes.

\section{Sobre el proceso de la transmisión de imágenes ${ }^{38}$}

Walter Benjamin consideró que con la incursión del cine se generaron acontecimientos visuales completamente nuevos, pues aunque desde el siglo Xv existían ya diversas técnicas de reproducción de la imagen como la xilografía, éstas finalmente alcanzaron un estatuto diferente mediante el sonido en el cine. A decir de Benjamin, al separarse la reproducción de su original y convertirse en una producción mecánica sin modelo, se hizo posible registrar ilimitadamente todo tipo de movimiento y mediante la edición de éste fue factible realizar cualquier montaje. Esta técnica de producción mecánica mediante aparatos basada en la fotoquímica puede llegar a comprenderse como un verdadero procedimiento generador de iconicidad. Si bien los nuevos aparatos y técnicas construyen al cine material y socialmente, el discurso sobre el cine no se circunscribe sólo al proceso técnico sino que se constituye también a partir del empleo de terminología que define "el modo de ver" y que ha de verse dentro de tradiciones de la estética o de la investigación de los medios masivos.

Un proceso similar ha tenido el tratamiento de los rayos $\mathrm{X}$ - visibles por primera vez mediante el cinematógrafo de Conrad Röntgen en I895, los hermanos Lumière y de los hermanos Skladanowsky. Gracias a ellos, los rayos X se consideraron como imágenes transmisoras de significado médico y científico. Desde entonces, su manejo se ha acompañado por un continuo desarrollo de aparatos para la visualización del interior del cuerpo. Las imágenes de rayos $\mathrm{X}$ que se producen con ecografías ya sea por computadora o con resonancia magnética, cuentan con una percepción altamente selectiva. Lisa Cartwright desde los estudios de cultura visual argumenta que al ser el diagnóstico el objetivo, se subordinan las constelaciones sociales del poder y de pericia que caracterizan la

Valeria Gringberg (Barcelona: Gedisa, 2009).

38. Con "proceso de transmisión de imágenes" (Bildgebendes Verfahren) se habla tanto de las imágenes del cine como de las de la ciencia y de la medicina, por ser imágenes transmitidas de un formato a otro con la ayuda de instrumentos técnicos, mediante cuyo proceso resultan imágenes diferentes. Esto a diferencia de las imágenes calculadas matemáticamente a partir de una serie de datos, también llamadas imágenes digitales. 
situación de producción y de significación de esas imágenes; ${ }^{39}$ la forma de ver dichas imágenes, a pesar de su diferencia, tiene lugar dentro de convenciones existentes de la imagen. Martina Hessler señala cómo las imágenes de rayos X se vinculan con la tradición científica de la curiositas en la época moderna que se vio comprometida con el registro, la medición y el estudio del mundo. ${ }^{40}$ Con lo anterior es posible llegar a la conclusión de que las imágenes obtenidas mediante aparatos resultan ser finalmente instrumentos poco neutrales para el acceso a la realidad. Su referencia con la realidad se crea en el momento de su percepción, no de su producción.

Como lo demuestran estos ejemplos, el concepto de "proceso de transmisión de imágenes" que es relativamente joven — probablemente utilizado por primera vez en la medicina en 1980 por Volker Kleinschmidt_— ${ }^{41}$ resulta poco delineado histórica y sistemáticamente aun cuando hoy se aplique mayoritariamente a la producción de imágenes científicas, como sucede en las diversas áreas donde las imágenes transmitidas juegan un papel constitutivo, como en la astrofísica, en la medicina, en la microscopía, en la física de partículas y en la mecánica cuántica. El común denominador de este proceso generativo de iconicidad radica en las mediciones del efecto físico de un objeto. Estas mediciones se convierten posteriormente en otras imágenes gracias a métodos diferentes. El efecto medido se percibe por lo general mediante un sondeo dirigido, por ejemplo con ultrasonido, radioisotopía o campos magnéticos. En este sentido se ha llamado especialmente la atención sobre el papel que juegan los aparatos utilizados en el proceso de generación de imágenes.

Así, Frank y Lange abordan la digitalización y sus aparatos, considerados como una nueva técnica de producción de lo visual. Además fungen al mismo tiempo como interfaz de todos aquellos registros generados mediante aparatos, ya que es posible integrarlos a la misma técnica de almacenamiento para poderse transformar. Esto ha abierto las posibilidades de visualización de cualquier tipo de dato, ya sea mediante algoritmos o también los acústicamente representados.

No obstante, es preciso recordar que la primera vez que los números se tradujeron en imágenes fue en I836, mucho antes de la era digital y de las interfaces

39. Lisa Cartwright, Screening the Body: Tracing Medicine's Visual Culture (University of Minnesota Press, 1995).

40. Véase Martina Hessler, Logik des Bildlichen: zur Kritik der ikonischen Vernunft (Bielefeld: Transcript, 2009).

4I. Véase Volker Kleinschmidt, Häufigkeit und Treffsicherheit bildgebender Untersuchungen des Galensystems (Friburgo: Hochschulschriften, I980). 
de usuarios en Windows e Internet, cuando los hermanos Weber para su libro Die Mechanik der menschlichen Gehwerkzeuge, ${ }^{42}$ al considerar las articulaciones y tridimensionalidad que implica cada movimiento en el espacio, establecieron ecuaciones de movimiento cuya tabla de resultados puramente numérica se convirtió en ilustraciones. Además, para destacar el papel que desempeñan las imágenes de matrices numéricas, Frank y Lange recurren al ejemplo del hawk eye empleado cuando se duda del juicio del árbitro en el tenis: con grabaciones de varias cámaras y con ayuda de un programa de computación especializado, el hawk eye sintetiza en un cálculo aproximado la curvatura de vuelo de la pelota que con gran probabilidad corresponde a la trayectoria real de la misma. En este momento se reproducen imágenes digitales detrás de cuya superficie visible se oculta determinado comportamiento numérico además de ciertas operaciones aritméticas.

\section{Simulacro y simulación}

Lo interesante de este fenómeno es que mediante el empleo de las imágenes digitales en el arte, en los medios, en las ciencias y la industria del entretenimiento, resulta problemática una clara demarcación de los límites entre uno y otro ámbito por su capacidad de transformación. Lo que de esta manera se cuestiona es el estatuto de simulación, de espejismo o copia de las imágenes, puesto que la imagen generada por cálculos matemáticos no implica un modelo original de arte; como el cine no reproduce a la manera de la fotografía análoga según los principios ópticos de la perspectiva. En caso de que la imagen efectivamente se refiera a una aparente realidad, su imitación (mimesis) es entendida entonces como una especie de camuflaje. La crítica y la teoría de los medios de comunicación buscan describir esto mediante conceptos complejos relativos al simulacro (imagen, reproducción, copia, espejismo, fantasma) y de simulación, como lo hubo de enunciar en su momento el sociólogo y filósofo francés Jean Baudrillard. ${ }^{43}$ La mayoría de estos enfoques filosófico-culturales diagnostican una influencia sobre la sustitución de la realidad mediante medios específicos como lo son particularmente los medios de comunicación masiva.

42. Eduard Weber y Wilhelm Weber, Die Mechanik der menschlichen Gehwerkzeuge (Gotinga: Dieterichschen Buchhandlung, I836).

43. Jean Baudrillard, L'Échange symbolique et la mort (París: Gallimard, I976). 
En este sentido de acuerdo con el filósofo y experto en informática Jörg Schirra, la visualidad computacional se aboca a investigar la mirada mecáni$\mathrm{ca}$ - reconocimiento de patrones - y a la elaboración automática de información óptica que, en el área de procesos de inteligencia artifical, posibilita la comprensión humana de las imágenes. ${ }^{44}$ Por su parte, para James Elkins esta área es necesaria ya que el conjunto de procesos de imágenes transmitidas y de imágenes generadas por matrices numéricas pone en cuestionamiento algo que se le había atribuido a las imágenes por mucho tiempo: el fungir como representantes al sustituir algo ausente. 45 Por último, no hay que olvidar que dentro de la multiplicidad del proceso de imágenes científicas es necesario valorar el papel constructivo de las ciencias - como las económicas, del derecho, la geología, arqueología y zoología - en la producción, retención y difusión de conocimiento mediante imágenes, así como sus formas de argumentación que son la expresión de una lógica visual específica.

\section{Imágenes invisibles}

Frank y Lange dirigen nuestra atención a la neurofisiología que utiliza imágenes como parte de sus experimentos cuyos resultados son traducidos simultáneamente en imágenes. Por ello, nuevamente, le compete a la Bildwissenschaft la especificidad de las dificultades de este campo de investigación, ya que la comunicación de dichos resultados está culturalmente codificada. Lo que la medicina produce en realidad de esta forma son imágenes técnicas de imágenes mentales o más exactamente: imágenes calculadas electroquímicamente de estados del cerebro que de manera simultánea, con la vista, y por la vista, son imágenes internas mensurables las cuales, a su vez, siguen sistemas de transcripción determinados por patrones culturales. La postura del neurobiólogo Gerald Hüther muestra qué tanto puede ampliarse la reflexión sobre el poder de las imágenes interiores, ya que él refiere que el mundo está lleno de imágenes para todos aquellos que

44. Jörg Schirra, "Computervisualistik (Die Bildwissenschaft der Informatik)", en Bildwissenschaft: Disziplinen, Themen, Methoden, ed. Klaus Sachs-Hombach (Fráncfort del Meno: Suhrkamp, 2005), 268-280.

45. James Elkins, Six Stories from the End of Representation: Images in Painting, Photography, Astronomy, Microscopy, Particle Physics, and Quantum Mechanics (Stanford University Press, 2008). 
pueden percibir con sus sentidos. ${ }^{46}$ Según Hüther la imagen se emplea como un concepto colectivo para todas las impresiones sensoriales. Para el autor es el cerebro el órgano productor de imágenes interiores — generador, almacenador y reconciliador de imágenes - y de su poderoso efecto. Al mismo tiempo amplía los alcances del concepto de imagen, cuando dice que fueron imágenes internas las visiones de los fundadores de las grandes religiones. Frente a esto, la Bildwissenschaft tiene la tarea de reflexionar más allá de los datos empíricos que le proporciona la neurofisiolgía y de reconstruir lo que el fenómeno de las imágenes internas tematiza para el individuo respectivamente: qué visiones y en particular cuáles representaciones visuales de imágenes internas se sujetan a modelos culturales, qué significan, qué pueden realizar y qué no, respectivamente. Como ejemplificación de dicha problemática se traen a colación los textos de Johannes Kepler, quien en su libro sobre la dióptrica ${ }^{47}$ — la lectura de la refracción de la luz- sostuvo que a través del lente de los ojos se proyecta una imagen al revés y de cabeza sobre la retina. Kepler sospechó que los órganos de la vista sobre la retina se estimulan con la luz. De este modo estableció la percepción visual como un fenómeno complejo de la estimulación del sentido. Aún resulta polémico cómo surgen y cómo se adquieren las imágenes internas en el cerebro, porque justamente son imágenes invisibles difícilmente detectables en su formación y figuración con los aparatos tecnológicos y digitales con que contamos hoy día.

Las imágenes interiores pertenecen al sistema mental que tiene una base en las conexiones neuronales y su actividad. La teoría de los sistemas sostiene que el sistema orgánico es imperceptible al sistema psíquico, de donde resulta la incomunicabilidad. A decir de Niklas Luhmann, de la misma forma en que la conciencia no puede comunicar, así tampoco la comunicación puede percibir. ${ }^{48}$ Klaus Sachs-Hombach sostiene que la teoría de las imágenes se concentra en su mayor parte en los tipos de representación de imágenes, en artefactos como la pintura, el dibujo, estatuas y parecidos. Sin embargo, además de éstos se encuentra también la imagen avenida de la óptica natural como el reflejo, la sombra

46. Véase Gerald Hüther, Die Macht der inneren Bilder. Wie Visionen das Gehirn, den Menschen und die Welt verändern (Gotinga: Vandenhoeck \& Ruprecht GmbH \& Co. KG, 2010).

47. Johannes Kepler, Dioptrice seu demonstratio eorum quae visui \& visibilibus propter Conspicilla non ita pridem inventa accidunt (Augsburgo: Francus, I6II).

48. Véase su Introducción a la teoría de sistemas (México: Universidad Iberoamericana, 1996). 
y la huella, mientras que las imágenes mentales internas como resultado de la percepción se manejan como mera percepción. ${ }^{49}$

De este modo la percepción se posiciona como un medio de suma importancia, ya que es el "umbral" entre lo interno y externo; es responsable de la proyección que hace una realidad interna a partir de la materialidad externa, así como la producción de una realidad exterior a partir de imágenes internas. De igual forma, la determinación del estatuto que obtienen los objetos exteriores depende de los modelos respectivos de la percepción en la teoría del conocimiento. A su vez, la determinación del estatuto que tienen las imágenes internas en la totalidad de los procesos psicológicos, depende de la psicología respectiva. Precisamente porque las imágenes mentales no son visibles, permiten un amplio espacio para la especulación. Robert Musil ya decía que se pueden hacer disponibles si se comunican visualmente mediante la expresividad artística, o si son habladas, adquieren convenciones expresivas. ${ }^{\circ}$ Esto nos demuestra una vez más que también las imágenes internas actúan bajo convenciones, en el marco de lugares retóricos o icónicos: en suma, surgen de percepciones codificadas y se transforman cultural y verbalmente. En este sentido y retomando a Michel Foucault: percibimos como pensamos. ${ }^{51}$ Así, la Bildwissenschaft cuestiona la construcción y la historicidad de estos parámetros gramaticales de la imagen y escribe así una historia del conocimiento relativo — variable — sobre la percepción, en el que nuestro conocimiento de la imagen se encuentra siempre involucrado.

\section{La existencia independiente de las imágenes internas}

En este sentido resulta pertinente preguntarse por la existencia independiente de las imágenes internas, cuestionando su supuesta dependencia con las impresiones sensoriales. ¿Cómo explicar que algo nuevo, jamás percibido, pueda pensarse, concebirse e imaginarse? De esta forma, es posible centrar la atención en la facultad de la imaginación que es el canal de cualquier tipo de creatividad.

La riqueza de este apartado nos muestra que la mayoría de los intentos por ordenar los amplios campos de la imagen instan a una diferencia binaria básica

49. Sachs-Hombach, "Introducción", en Bildwissenschaft: Disziplinen, Themen, Methoden, 19-20.

50. Robert Musil, Ensayos y conferencias, trad. José Luis Arantegui (Madrid: Antonio Machado Libros, I992).

51. Michel Foucault, El orden del discurso, trad. Alberto González Troyano (Buenos Aires: Tusquets Editores, 1992). 
y estable que garantice el criterio de imagen tanto externa como interna, real e imaginaria o material e inmaterial, así como la diferencia entre objeto y percepción, imaginación y representación, picture, tableau o imagen. Sin embargo, a decir de Boehm, esta separación elemental se prueba como inestable y no consensual, ya que la extensión del concepto de imagen contiene elementos heterogéneos. ${ }^{52}$ De la "familia de conceptos" ha hablado ya Oliver Scholz desde la filosofía. ${ }^{33}$ Sin embargo, este tipo de separación básica, entre imágenes internas y externas es problemática, como lo sugiere Mitchell, ya que las imágenes interiores necesitan de un medio de exteriorización que a su vez ha de tomarse en cuenta.

Para la manera que tienen las imágenes interiores de expresarse, mediante la palabra o señas, resulta fructífero traer a colación el método psicoanalista de Freud, según quien las imágenes recordadas y los sueños se hacen accesibles al terapeuta, al aceptar una relación igual entre las imágenes mentales y las habladas, así como entre las percepciones objetuales y las imágenes mentales. Resulta útil aceptar esta relación aunque esté sujeta no sólo a diferentes, sino a interpretaciones contrarias (las del psicoanálisis y su crítica), ya que arroja luz sobre una problemática que se puede documentar históricamente, mas se manifiesta como resultado de demandas ideológicas eurocéntricas del siglo xviII. En este contexto, el modelo de percepción de objetos exteriores estaba subordinado a las imágenes internas y a la lengua. Este modelo sirvió a la publicidad burguesa donde la lengua, los conceptos abstractos y la prudencia se relacionaron como contraparte de las percepciones y de la visualidad del mundo exterior, lo cual condujo a la exigencia de una rehabilitación de la autonomía de la producción artística y de la estética.

$\mathrm{Al}$ tener en cuenta este desarrollo es preciso revalorar las cualidades sensoriales de la lengua que también son perceptibles, ya que se manifiestan y por tanto son reconocibles en la voz, además de que al manifestarse en la escritura dejan una huella visible que puede a la vez ser atendida como una percepción pictórica tal como sucede en la lírica visual del barroco o en la moderna. Éstas constituyen un lazo entre lengua e imagen. Según Elkins su oscilación entre escritura y grafía contiene variedades conocidas de un amplia riqueza de sistemas gráficos

52. Gottfried Boehm, "Das Bild in der Kunstwissenschaft. Interview mit G. B.”, en Wege zur Bildwissenschaft. Interviews, ed. Kaus Sachs-Hombach (Colonia: Halem, 2004), II-2I.

53. Véase Scholz, Bild, Darstellung, Zeichen. 
de notación y de pseudoescrituralidad. ${ }^{54}$ En este sentido, la relación entre texto e imagen ha demostrado constituirse en un campo fructífero de discusión en torno a la generación icónica y de visibilidad, donde conceptos retóricos han logrado poner de manifiesto su potencial icónico, como la écfrasis, el arte de la descripción visual (la metáfora y el emblema). Al respecto, Mitchell habla de los image-texts, con los que indica las interfaces entre lo verbal y lo visual. 55

\section{Camino del análisis: las imágenes en la práctica simbólica}

\section{La mirada y el pensamiento visual}

Ante el panorama presentado, los autores de la antología muestran una vez más que resulta imposible buscar una definición para lo que es una imagen. Lo único claro es que ante la diversidad de posiciones, reflexiones y argumentaciones surgidas a partir de esta pregunta, las imágenes son otra cosa que el lenguaje y dependen prioritariamente de la visión y de la experiencia sensorial del mundo. Es por ello que los autores dedican su tercer apartado al estudio y explicación del funcionamiento de la percepción humana delineando así una morfología de la imagen. La percepción actúa con una cooperación de cinco sentidos diferentes, cuyos incentivos se registran por millares de células nerviosas que en un complejo cableado de uniones de células permiten delinear representaciones mentales del mundo exterior. En el proceso de la vista, los nervios visuales responden a la luz. Ellos diferencian las longitudes de onda que nosotros percibimos como colores diferentes, además de que determinan formas y tamaños. El brillo, el color, la forma y el formato se capturan siempre de manera relacional y no absolutamente. Los criterios formales dependen así de patrones normativos, de tal forma que la atención, a decir de Jonathan Crary, ${ }^{56}$ no sólo es resultado de la estimulación nerviosa, sino que es profundamente dependiente de la cultura (a lo que se le llama experiencia interpretada).

54. James Elkins, The Domain of Images (Londres: Ítaca, 1999).

55. Respecto a la relación entre lo verbal-intelectual y lo visual-material, véase Mitchell, Picture Theory: Essays on Verbal and Visual Representation. Con relación al papel de la ideología otorgado por Mitchell, vinculado a la interpretación de las imágenes, véase del mismo, What do Pictures Want? The Lives and Loves of Images.

56. Véase Jonathan Crary, Suspensions of Perception: Attention, Spectacle and Modern Culture (Massachusetts: MIT, 2000). 
De igual manera, quienes producen imágenes operan invariablemente con convenciones visuales epistémicas. A decir de Dieter Mersch, ${ }^{57}$ el ilusionismo o antiilusionismo que crean es siempre mediado y susceptible de ser aprendido. Una prueba fehaciente de que el cerebro humano es extremadamente educable es el cine, donde se crea la ilusión de movimiento (mediante tomas de imágenes aisladas colocadas en serie a gran velocidad), y que una vez que el cerebro ha aprendido esta modalidad de ver, puede reutilizarla en el futuro. El énfasis de la frontera entre la representación de la imagen y el mundo viviente real debe verse como una práctica cultural que se vincula con una disposición mental inserta en una cultura de la mirada continua y ampliamente diferenciada, proporcionando así información sobre la función respectiva de las imágenes y sobre sus multifacéticos nexos con la experiencia visual. Así pues, la Bildwissenschaft piensa que el concepto de morfología de la imagen no sólo se restringe a ser una investigación de la estructura de cada imagen, sino que más allá se refiere a su incorporación en el sistema de la cultura visual correspondiente.

\section{Materialidad de las imágenes}

Junto con la reflexión sobre procesos de percepción surge la pregunta por la materialidad, un cuestionamiento que a decir de Peter Wagner había obtenido poca atención debido a que en las teorías del arte se había dado prioridad a la forma sobre el material. ${ }^{5} \mathrm{El}$ sentido de la vista puede, con base en el grado de reflejos de luz y sobre sus experiencias percibidas por el sentido del tacto y almacenadas en la memoria, reconstruir la materialidad de lo que está frente a los ojos. Asimismo las cualidades materiales brindan distintas relaciones de sentido que instigan a un modo diferente de coherencia de significación. La materialidad es una connotación temporal específica; sobre su base, las imágenes se vuelven temporales: ellas envejecen o se disuelven casi completamente. Sobre la degradación o descomposición, se hace perceptible la materialidad y por ello también la medialidad de una imagen. Preciso es tener en cuenta que la materialidad en sí no es lo determinante, sino su funcionalidad dentro de determinado orden simbólico.

57. Véase Dieter Mersch, Medientheorien zur Einführung (Hamburgo: Junius, 2006).

58. Peter Wagner, Icons. Texts, Iconotexts: Essays on Ekphrasis and Intermediality (Berlín/ Nueva York: Walter de Gruyter, 1996). 


\section{Intericonicidad y la imagen mimeografiada}

Ahora bien, aunado al aspecto material, otra cuestión que dota de sentido a las imágenes y sobre el cual llaman la atención los autores es el de la intericonicidad. De acuerdo con Julia Gelshorn, por intericonicidad ha de entenderse cómo las imágenes se interrelacionan entre sí, ya sean grupos de imágenes con géneros de imágenes o con otros medios, de manera intencional o sujetas al contexto, a medida que se reproducen, citan, parodian o comentan. Esto nos indica, la movilidad de las categorías de la imagen en la práctica diaria, así como sus redes de creación de significado. Mientras Pfister y Broich ${ }^{59}$ han llevado a cabo una construcción teórica multifacética y controversial para el respectivo concepto, la práctica analítica de la Bildwissenschaft se encuentra todavía en el comienzo de esta empresa. A decir de Gelshorn, una adopción directa del concepto de intertextualidad no es un código de práctica factible para guiar un análisis, debido a que las referencias de las imágenes pueden ser más difusas que en los textos, por lo que requiere de modificaciones necesarias. ${ }^{60}$ Como propuesta se expone el concepto colectivo de palimpsesto sugerido por Gérard Genette al perfilarse como más abierto a tomar en cuenta la materialidad. Si bien etimológicamente significa el rasurado del pergamino como preparación para nuevos usos, y por ello se vincula con una práctica escritural, implica una invasión en la materialidad de las superficies sobre las que se escribe, dibuja o pinta. Para Genette, la sistematización del concepto de intertextualidad demanda una designación precisa para una amplia serie de modos de referencia — una cita, alusión, plagio o metatextualidad - además de coadyuvar a introducir un cambio de planos como sucede mediante el comentario. ${ }^{6 \mathrm{I}}$ Genette distingue también los diferentes planos de referencia entre ellos, a saber, la arquitextualidad, la convención de género o la paratextualidad, como accesorios materiales y simbólicos de la obra. Todos estos fenómenos se pueden detectar también en los artefactos visuales.

En este punto, se retoma el término de polisemia utilizado por Genette. Para él la hipertextualidad distingue modos de relación lúdicos como la parodia y el pastiche de formas satíricas, o bien el travestismo hasta formas más serias. En sín-

59. Ulrich Pfister y Manfred Broich, Intertextualität: Formen, Funktionen, anglistische Fallstudien (Tubinga: Niemeyer, 1985).

6o. Julia Gelshorn, "Interikonizität", Kritische Berichte (Mythen der Kunstwissenschaft) 3, núm. 35 (2007): 53-58.

6I. Véase Gérard Genette, Palimpsestos: la literatura en segundo grado, trad. Celia Fernández Prieto (Madrid: Altea/Taurus/Alfaguara, 1989). 
tesis, dejar que lo extraño incursione en lo propio permite un enriquecimiento con significados adicionales que pueden actualizarse por recipientes probables. La manera de abordar este aumento de complejidad visual resulta en una descripción densa que delinea formas de comprensión en el marco de conocimiento y prácticas culturales para posibles recipientes. Entre más diferencial sea el conocimiento y la competencia icónica de una cultura, tanto más significaciones culturales pueden cruzarse potencialmente en un artefacto visual. Sin embargo, no ha de entenderse como conducente a una arbitrariedad de significados que pueden ser libremente asociados, sino que la compleja estructura de las imágenes obliga a una observación atenta e interpretación de los efectos que conducen a la manifestación de la presencia de varias culturas.

Por tanto, no sólo existe un orden en el que se mueve la imagen, sino que se entrelaza en varios órdenes. Un análisis crítico de la Bildwissenschaft debe cuestionar cómo la mirada se organiza y cómo se construyen jerarquías de imágenes.

En la medida en que las reproducciones hicieron accesibles los originales a un público mayor mediante réplicas de pequeño formato, gráficas de reproducción o fotografías fácilmente transportables, éstas pueden considerarse como un importante instrumento de propagación e implementación de imágenes. Con frecuencia causan una mayor impresión en la memoria y encubren con ello el cambio de medio y de tamaño. El principio de multiplicación causa principalmente que muchos observadores vean lo mismo, pues tienen materialmente lo mismo ante los ojos y con ello la misma impresión óptica sobre la retina. A decir de Ingeborg Reichle, la mirada conjunta de imágenes iguales conduce sobre todo a la reflexión sistemática sobre los modos de representación de imágenes. ${ }^{62} \mathrm{La}$ fotografía toma aquí un papel especial por su carácter de índice y como medio objetivo de representación al fungir como importante herramienta manual en la historia del arte, como apuntó Angela Matyssek. ${ }^{63}$ De esta forma Frank y Lange concretan que se desarrollaron procedimientos de análisis de las imágenes relativos a la percepción con base en una importante masa de reproducciones fotográficas de obras de arte, las cuales hicieron posible el intercambio y la comparación de objetos en diversos lugares.

62. Ingeborg Reichle, "Kunst-Bild-Wissenschaft. Überlegungen zu einer visuellen Epistemologie der Kunstgeschichte", en Verwandte Bilder. Die Fragen der Bildwissenschaft, eds. I. Reichle, Steffen Siegel et al. (Berlín: Kulturverlag Kadmos, 2007), I69-I89.

63. Angela Matyssek, Kunstgeschichte als fotografische Praxis. Richard Hamann und Foto Marburg (Berlín: Gebr. Mann Verlag, 2009). 
Se destaca que desde finales del siglo xix las películas, la televisión y el video han establecido formas de imágenes que no se diferencian más entre el original y la reproducción; ni la imagen misma ni su implementación material deciden sobre las condiciones de la percepción, sino que las condiciones de recepción y las oportunidades de acceso a la tecnología correspondiente son las que determinan si y desde dónde pueden verse estas imágenes plurales.

\section{Camino del análisis: las imágenes como práctica social}

\section{Régimen de la mirada}

$\mathrm{Al}$ retomar las conclusiones anteriores, de que la imagen es producto de algunas relaciones que la percepción comprende, complementa o rechaza, los autores enfatizan que las imágenes se encuentran en cambios de relaciones unas con las otras y por tanto están siempre integradas a una ejecución. En la historia social bajo Theodor Adorno, el camino se dirigía hacia la lógica de la producción de las obras artísticas, es decir, hacia la huella que los comportamientos sociales imprimieron sobre su forma, contenidos y temas. En contraparte, Frank y Lange exponen que la nueva historia social y la ciencia cultural se interesan por aquello que la imagen produce a la misma sociedad y sobre todo a los individuos. Las imágenes de hecho llevan — tanto si son obra de arte o no- las huellas de la sociedad, también por eso condicionan su estado. Así el tema central propone un cambio distintivo: anteriormente se ubicaba la reflexión en los lugares de producción, en artistas, coleccionistas y mecenas, mientras que actualmente se centra en los destinatarios y en la facultad formativa de las imágenes sobre su espectador.

Las ciencias naturales del siglo xIx buscaron la frontera entre la retina, el cerebro y el alma. De esta guisa se formularon las preguntas: ¿cómo funciona la percepción? ¿cómo funciona la psique? y ¿cuáles condiciones considera la elaboración mental de las impresiones ópticas? Los experimentos sobre la psicología de los ojos buscaron enlazarse con la óptica física para poder separar los aspectos especulativos de la filosofía del conocimiento respecto al origen de las ideas en el cerebro. Las investigaciones psicológicas contribuyeron a ese fin, no sólo en lo corporal, sino también respecto a la dependencia psíquica de los procesos de la vista y con ello hicieron entendible y consideraron igualmente importante la impresión de la vista al momento que desarrollaron las leyes de la 
óptica. Con base en la Teoría de los colores, de Goethe (I8I0) ${ }^{64}$ y el Manual de la óptica psicológica, de Hermann Helmholtz (I 867) es posible resumir este campo de investigación, pues no sólo se establece que la anatomía de los ojos conoce la duplicación de la percepción óptica en la estimulación de los conos y bastones de la vista sobre la retina, sino que también esclarece finalmente que es el cerebro el que une dichas estimulaciones aisladas sensoriales y las interpreta.

El interés por una misma mirada de la visión continuó en el psicoanálisis, pues la mirada se vuelve activa en el proceso de construcción conjunta de pensar el mundo. Jacques Lacan empleó la mirada como el proceso por medio del cual el hombre se ubica dentro del espejo del mundo, pues al mismo momento que ve, es visto. Así la autoconciencia y la individuación dependen de la autorreflexión en el espejo. ${ }^{65}$ Frank y Lange explican que para Lacan el sujeto se origina en el punto de intersección entre la "vista" producida por él, y la "mirada” predispuesta que casi siempre reposa en sí, y al que el sujeto se orienta en su comportamiento.

\section{Escopofilia, mirada cultural, régimen escópico}

En 1975 Laura Mulvey utilizó la teoría de Lacan sobre la mirada a la escopofilia del cine clásico de Hollywood, añadiéndole una perspectiva feminista, la cual le permitió analizar y criticar a ese cine como un aparato que instaba al espectador al inevitable papel de hombres. Por otra parte impedía a las espectadoras identificarse con los personajes femeninos que estaban representados como objetos. Con ello, Mulvey llegó a clasificar dos variantes de la mirada: la "voyerística" que exhibe a las mujeres como objetos subyugados, y la curiosidad "fetichista" en donde se les veía como objetos admirables. ${ }^{66}$

Katja Silverman complementó el concepto ahistórico de Lacan desde constantes sujetos antropológicamente percibidos en la amplias comparticiones sociales, culturales e ideológicas, en la "mirada a través de 'la mirada cultural". ${ }^{67}$

64. Johann Wolfgang von Goethe, Teoría de los colores, trad. Javier Arnaldo (Valencia: Consejo General de la Arquitectura Técnica en España/Celeste Ediciones, 1999).

65. Jacques Lacan, Le Séminaire, tome II: Les Quatre Concepts fondamentaux de la psychonalyse (París: Seuil, I964).

66. Laura Mulvey, "Visual Pleasure and Narrative Cinema," Screen I6 (3), (I975): 6-18.

67. Katja Silverman, "Dem Blackregime begegnen”, en Privileg Black. Kritik der visuellen Kultur, ed. Christian Kraragna (Berlín: ID-Archir, I997), 4I-64. 
Para Silverman es el régimen de la mirada, con el orden social masculino por medio de la producción de determinadas imágenes, un consenso social "una ficción dominante", el cual justifica y asegura un comportamiento de poder producido y existente. La producción de algunas imágenes que refieren papeles y posiciones sociales ha reemplazado en ese concepto las relaciones de propiedad como lugar de dominio político económico. Para el artista y cineasta francés Guy Debord se trata de la transición de una sociedad de clases interesada en el viejo marxismo hacia una "sociedad del espectáculo". ${ }^{68}$

Por su parte, la investigadora Lisa Cartwright discutió que la historia del análisis corporal y la vigilancia médica se encuentran atadas a la historia del cine como institución de cultura popular y como aparato tecnológico. ${ }^{69}$ De esta manera la mirada descrita cobra un efecto controlador mediante el cual la formación de las obras visuales del recipiente, en interacción con su disposición psíquica, le asigna una posición determinada y lo forma social, psicológica y físicamente. Es así cómo el teórico del cine francés Christian Metz estableció el concepto de régimen escópico para esta correlación de instituciones, para este gobierno de la visión característico y para la formación de los espectadores, lo cual demuestra no sólo la variabilidad histórica de los sentidos, sino también su específica dependencia de las instituciones sociales. ${ }^{70}$

Frank y Lange exponen cómo esta reconstrucción de la "mirada" determina el orden del conocimiento que controla la vista de los espectadores. El texto señala cómo Erwin Panofsky buscó por primera vez rastrear sistemáticamente uno de esos órdenes con el método de la iconología. Sobre una descripción de la forma y de contenido fuera de la imagen, la iconología determina principios subyacentes básicos de una sociedad que se revela modificada por medio de la personalidad y compactada en la obra. Panofsky se ocupó de la interpretación de este valor "simbólico". Con la postura de que la creatividad individual siempre está implicada en un orden colectivo — su iconología—, Panofsky inauguró el punto de vista analítico en la historia del arte, perspectiva que fue valiosa para otros desarrollos dentro de la teoría de la cultura, ocupados también en la práctica de las imágenes y del arte.

68. Guy Debord, La Société du spectacle (París: Lebovici, 1987).

69. Cartwright, Screening the Body.

70. Véase Christian Metz, Le Significant "imaginaire": "psychanalyse et cinéma" (París: Bourgois, 1984). 
En cierto sentido heredera de la iconología de Panofsky se encuentra la postura de Mitchell, quien desarrolla su iconología al lado del marxismo de Louis Althusserl, al destacar el papel ideológico. Por su parte, Pierre Bourdieu adoptó el concepto de habitus de Panofsky, desarrollándolo como un concepto de internalización y de imitación reconocible de actitudes colectivas básicas. Frank y Lange consideran que siguiendo la sociología de Bourdieu y el análisis del discurso de Foucault, la Bildwissenschaft puede completar la teoría de Panofsky al identificar la teoría de los otros con el poder de los órdenes de conocimiento incorporados socialmente.

\section{Discurso o viscurso}

Para Frank y Lange, la Bildwissenschaft toma su objeto no sólo como síntoma y documento real de procesos sociales, ideológicos y científicos, sino que para describir su virtud independiente, considera su fabricación y su implementación de órdenes del conocimiento. De esta manera surge el concepto viscurso. El discurso y el viscurso comparten aspectos esenciales. El concepto de discurso de Foucault no está limitado al texto, sino que se encuentra en un entrelazamiento de prácticas verbales y no verbales. La Bildwissenschaft retomó el concepto pero desplazó la atención del análisis del discurso, del texto a la imagen. Para Knorr-Cetina el concepto de viscurso debe enfocarse en su interacción con representaciones visuales, así como en su incorporación a un discurso continuo. ${ }^{7 \mathrm{I}}$

El término viscurso proviene de la científica Karin Knorr-Cetina, quien en un estudio de física de altas energías detectó la relevancia de las representaciones visuales en el proceso de investigación, tanto para encontrar y clasificar los objetos de investigación como para comunicar los resultados y establecer consensos sobre los resultados de la investigación en las comunidades de especialistas. Así, el viscurso se mueve sobre sistemas de la imagen anteriores, de cuya combinación y variación asocia cantidades de conocimiento con el objetivo de producir nuevo conocimiento.

Los autores de la antología explican cómo en la teoría los viscursos se sirven de un simbolismo colectivo, el cual modela el actual conocimiento de la imagen y de la memoria visual de una cultura y que puede ser representado visual y verbal-

7I. Karin Knorr-Cetina, Wissenskulturen. Ein Vergleich naturwissenschaftlicher Wissensformen (Fráncfort del Meno: Suhrkamp, 2002). 
mente. Sin embargo, los viscursos son cantidades controladas de visualización que pertenecen a un sistema de pensamiento y argumentos (también con imágenes). Ambos tienen en común un objeto determinado y una cantidad de reglas de manufactura con las imágenes, modelos o animaciones de tres dimensiones. El viscurso establece que estos artefactos deben cumplir con ciertos requisitos y estar en determinadas relaciones. De esta forma las imágenes pueden volverse la ejemplificación de problemas abstractos y así sus funciones pueden ser reconocidas como insustituibles por el origen del conocimiento que brindan. La relevancia de lo visual se ha probado en estudios donde las imágenes brindan un mayor conocimiento que los escritos, como lo prueba Julia Voss respecto al contenido de los dibujos de Darwin. ${ }^{72}$

\section{La memoria visual: el mundo de la cultura visuallla cultura visual del mundo}

En este apartado Frank y Lange retoman las investigaciones realizadas por el psicólogo cognitivo Frederic Bartlett en 1930 quien se interesó por la capacidad pictórica de la memoria. Observó que la temporización de lo recordado y la influencia social, marcada por el contacto con culturas ajenas, favorecen un estereotipo de formas y de contenido. En cada sujeto hay un trasfondo cultural que permite la interpretación de la imagen, interpretación que Bartlett describió como "patrón de desarrollo activo", 73 el cual es el encargado de realizar el anclaje sociocultural de la imagen visual.

Otros investigadores que trabajaron teorías de la memoria pictórica fueron Walter Benjamin, Aby Warburg quien incluso desarrolló un modelo para buscar el cruce cultural y temporal de las fórmulas de las imágenes impresas o bien acuñadas en la memoria. El sociólogo Maurice Halbwachs tematizó el marco social del recuerdo individual, y sus observaciones nos guían al análisis de una memoria colectiva que explica que mediante la cooperación en la práctica social se forman las imágenes. ${ }^{74}$ Dentro de las ciencias de la cultura las recientes teorías de la memoria retoman el concepto de memoria supraindividual de la imagen

72. Voss, Darwins Bilder.

73. Frederic Bartlett, Remembering: A Study in Experimental and Social Psychology (Cambridge University Press, 1932).

74. Maurice Halbwachs, La Mémoire collective (París: Presses Universitaires de France, I950). 
que data de principios del siglo xx. Para Frances Yates todos estos modelos refieren a la capacidad del cerebro humano de usar imágenes que reposan en un espacio de mnemotecnia establecida, lo cual aporta una disposición para estructurar recuerdos de lugares y de imágenes. Así, la estructura de la memoria está implícitamente dada por medio del espacio y de la imagen. ${ }^{75}$

Los autores no pierden de vista por igual que en la memoria visual se localizan asimismo las elaboraciones visuales de los encuentros, las comparaciones y los conflictos de las culturas, de donde unas imágenes son definidas como imágenes de los otros e imágenes ajenas a lo propio. Esta "otredad" puede ser un fragmento de la misma sociedad; también puede localizarse allende los límites de la cultura. En este contexto la Bildwissenschaft ha orientado su atención a dos encuentros culturales: al llamado "descubrimiento" desde la visión europea de un nuevo mundo que recibió el nombre de América, y al debate respecto a la cultura del sudoeste asiático y del norte de África, que ha inspirado la fantasía de los europeos bajo la denominación de lo "oriental".

\section{Lo moderno como cultura visual}

Los autores señalan cómo la Bildwissenschaft resulta de experiencias con las imágenes propagadas por los medios masivos en la modernidad, las cuales desde I929 guiaron a autorreflexiones fundadas en teorías sobre la cultura de la imagen, y para la década de 1960 cobraron matices críticos. Desde 1929, pero principalmente en la década de 1930, se puede ubicar lo que Frank y Lange llaman "la primera Bildwissenschaft”, expuesta mediante los trabajos de Warburg, Panofsky y Benjamin, quienes fungieron como autoridades, y de Rudolf Arnheim, Béla Balázs, Carl Einstein, El Lissitzky y Siegfried Kracauer. En este nuevo medio de imágenes fluyó la crítica a la lengua y a todas las manifestaciones de la vida de fin de siglo dominada por las tradiciones, lo cual era apuntalado por el historicismo. En este contexto Hugo von Hofmannsthal puso en alto el papel de las artes "silenciosas", como la música, la danza y las artes acrobáticas. Así, el cine mudo fue exitoso, junto con todo este arte de movimiento del cuerpo no basado en la palabra y que une más sentidos.

75. Frances Yates, The Art of Memory (Londres: Routledge y Kegan Paul, I966). 


\section{Conocimiento icónico}

\section{Visibilidad y capacidad de expresión}

En este apartado se retoma el hecho de que la Bildwissenschaft se encuentra en el inicio en muchas de sus áreas de trabajo, y, sin embargo, brinda una gran serie de sugerencias sobre teoría de la enseńanza y desarrollo metodológico a la historia del arte, a la sociología, a la etnología y a los cultural studies.

La Bildwissenschaft pone atención especialmente a la discusión de la diferencia entre la imagen y los signos lingüísticos. De acuerdo con Hans Belting, una imagen no reemplaza a un signo, ni viceversa. Como lo han mencionado Boehm, Bredekamp, Debray y Mitchell, actualmente la lucha contra el dominio de la palabra se encuentra en el supuesto de una exclusividad mutua. Elkins sostiene que la crítica a la semiótica se dirige mayormente contra sus supuestos de una codificación y de una capacidad de decodificación (legibilidad) de las imágenes. La Bildwissenschaft duda que las reglas convencionales para la asignación de signos y significados pueda ser válida también para las imágenes, especialmente para las obras de arte. Sobre todo rechaza la idea de una retraducción de un mensaje encriptado estéticamente de un texto por lo común comprensible. Eva Schürmann ${ }^{76}$ alega por la inconclusividad de una interpretación de la obra de arte, ya que las formas de procedimiento estético nunca han podido establecerse sobre una univocidad de la comprensión. O dicho de otra forma, su contenido real de alguna forma siempre debía ser inexpresable.

Schürmann se enfoca en la estructura de determinadas condiciones que influyen en la percepción. Ella considera que varios elementos no verbales de una imagen son percibidos como portadores de significado, de los cuales el observador hace una selección y luego utiliza para un significado potencial, o primario. A decir de Michael Titzmann, este proceso de selección se basa en la psicología de la percepción, en las regularidades neurológicas y en la codificación convencional de la cultura. Refiere que las atribuciones de significaciones secundarias pueden basarse más en la codificación cultural mediada lingüísticamente. ${ }^{77} \mathrm{De}$ esta forma, Titzmann llegó a la conclusión de que son imágenes concretas las que

76. Véase Eva Schürmann, Die Medialität der Medien (Tubinga: Universitätsbibliothek Tübingen, 2010); y de la misma Sehen als Praxis.

77. Michael Titzmann, "Interaktion von Text und Bild", Medien un Kommunikation. Eine interdisziplinäre Einführung, ed. Hans Krah (Passau: Stutz, 2006), 215-248. 
indican un objeto único en estados sincrónicos, sin brindar mayor seguimiento diacrónico; por otra parte constituyen "clases abstractas" y pueden "formular reglas". Son incapaces de ser "abstracciones generalizadas". Estas imágenes pueden asignar sólo un objeto concreto, a diferencia de las imágenes que pueden ofrecer una semantización de los elementos de la imagen.

Por su parte, Elkins busca en la mirada los diversos lazos entre la imagen y la escritura, para deducir y sistematizar: la alografía (todas las variaciones de lo literal, sin que su estatus se modifique), la pseudo o quasiescritura, el sub y el hipografema (capacidad visual inmediata, no identificable con la escritura). ${ }^{78}$ Frente a esta variante de la semiótica, Mitchell desarrolló su teoría de la imagen. Él critica a la corriente semiótica por su exclusivo interés en la producción de significado, para él las imágenes son más que signos de algo más. Mitchell diferencia cuando menos tres planos: la coyuntura problemática de imagen/texto, la obra o concepto compuesto de imagen/texto y los planos de relaciones con lo visual y lo verbal.

Mitchell también descubrió en las imágenes diferentes estrategias que señalan el estado de desarrollo de las imágenes y con ello la capacidad de descubrir las historias. La secuencia de eventos no ilusionistas se representan dentro de un espacio, en diferentes lugares. Mitchell señala que las imágenes permiten hacer afirmaciones generalizadoras, por lo que para él es posible llegar a construir teorías a partir de las imágenes. De ahí que de acuerdo con él, las imágenes pueden también tener metaniveles, como las llamadas metaimágenes o hypericonos, sobre los cuales ellas se representan, comentan y negocian, con ellas mismas y con sus precondiciones. ${ }^{79}$

Frank y Lange ubican el surgimiento de semióticas propias de la imagen y de la música como contraparte de las desarrolladas por Charles Sanders Peirce y por Ferdinand Saussure que mantenían a estas disciplinas bajo el modelo de la lengua. En estas nuevas semióticas se han desarrollado criterios que proponen la diferenciación entre la música, la imagen y la lengua, y donde cada una tiene una forma diferente de construcción. En esta corriente, Mieke Bal diferencia un plano subsemiótico sobre el que se localizan las técnicas de producción y un plano suprasemiótico para la representación visual. ${ }^{80}$ La Bildwissenschaft y la

78. Elkins, The Domain of Images.

79. Véase n. 5 .

8o. Mieke Bal, Reading "Rembrandt": Beyond the Word. Image Opposition (Cambridge University Press, 1998). 
semiótica no son partes de la misma disciplina. Para Elkins, la semiótica requiere la competencia de diferentes planos, que podrían ser completamente específicos tanto para la imagen, la lengua o la música. No obstante existe una frontera, la competencia de la semiótica no es de la competencia de la historia de la imagen, pues no es una competencia material ni de producción.

\section{Código, minimalismo y principios de las acciones racionales}

Roland Posner coloca la especificidad de la imagen debajo del plano del código, permitiendo una gran cercanía entre la imagen, el lenguaje y la música, su "código minimalista” se basa en una espontánea interpretación pragmática relacionada con el contexto y la situación de los actos sociales, junto con algunos principios de interacción. ${ }^{8 \mathrm{I}}$

La Bildwissenschaft está menos interesada en una continuación de la disputa entre imagen o signo que en su solución mediante la reconstrucción histórica del conflicto. Sintetizan este conflicto las preguntas formuladas por Frank y Lange: ¿De dónde viene y qué significa?, ¿quiénes se benefician? y ¿qué dañan con sus exclusiones?

Hemos visto que la Bildwissenschaft, como proyecto interdisciplinario de análisis e interpretación de la cultura de la imagen, se ha enfocado en el terreno de las ciencias históricas, la filosofía, la fisiología, la psicología y la neurología, así como en la ciencia de los medios y en la informática. Ella toma información de la política y de las ciencias sociales respecto a la distribución cuantificable, como al efecto, de las abundantes imágenes generalizadas por la publicidad en el tipo de vida individual, así como en las organizaciones e instituciones que accionan la producción y distribución de estas imágenes.

En este sentido, reconoce que la incertidumbre respecto al concepto de imagen, visualidad y cultura manejada en la Bildwissenschaft conlleva a dificultades, las cuales, como se expuso anteriormente, más que problematizar o entorpecer las investigaciones, pueden enriquecerlas. La interdisciplinariedad de la Bildwissenschaft permite aproximarse al objeto de investigación en tanto que su eclecticismo sirve para la integración de teoría y la modulación del conocimiento en una disciplina.

81. Roland Posner, "Ebenen der Bildkompetenz", en Was ist Bildkompetenz? Studien zur Bildwissenschaft, ed. Klaus Sach-Hombach (Wiesbaden: Deutsche Universitätsverlag, 2003), I7-23. 


\section{Conclusiones}

Ya vimos cómo los problemas actuales frente al estudio de la imagen no pueden resolverse desde las disciplinas separadas de la historia del arte, la ciencia de los medios o las ciencias de la naturaleza en general. Por el contrario, con la finalidad de buscar una comprensión del fenómeno actual de la imagen y de tratar de responder a incertidumbres o suposiciones respecto a cuestiones icónico-visuales en general —_ no sólo a la imagen del arte_- dentro de la sociedad contemporánea - por ejemplo, su posición como factor activo en la difusión de una cultura hegemónica occidental, o como medio de conocimiento para la física y la medicina_-, se han desarrollado varias posturas teóricas enfocadas en el tratamiento de diversos tópicos de la imagen. Así se ha logrado un compendio ecléctico de proposiciones y definiciones que, contrariamente de alejar el conocimiento respecto a la imagen, originan novedosas reflexiones, tanto sobre el quehacer del estudioso, como sobre la naturaleza de la imagen, nuestra percepción y el papel que cobra en nuestra sociedad.

Aunque el proyecto de la Bildwissenschaft no ha logrado su consolidación como ciencia, este compendio realizado por Frank y Lange presenta diferentes posturas con las cuales los estudiosos preocupados por la imagen trabajan sobre todo desde Alemania, aunque los estudios no se centran sólo en ese país. Parte importante del desarrollo de la Introducción a la Bildwissenschaft consiste en contextualizar los avances de la ciencia de la imagen, cuyos inicios se ubica a finales del siglo xix y principios del xx con pioneros como Aby Warburg, Walter Benjamin y Erwin Panofsky, y en cuya historia se engarza la propia historia del arte, considerada como resultado de específicas prácticas culturales de la forma de percibir, ver y consumir imágenes.

La Introducción a la Bildwissenschaft hace una conveniente exposición de historiografía del arte y de estudios vinculados con la imagen en general, mediante la cual presenta ideas que invitan a profundizar y a desarrollar temas fértiles para la investigación. Interesante resultaría, y queda como tarea, rastrear, documentar y analizar su recepción en el mundo hispanohablante, ${ }^{82}$ pues un debate en torno a qué son las imágenes, cómo funcionan y cuáles son sus campos de

82. Por ejemplo la antología de textos publicada después del estudio que aquí se reseña: Filosofía de la imagen, ed. Ana García Varas (Universidad de Salamanca, 20Ir); Fernando Rodríguez de la Flor, Giro visual (Salamanca: Delirio, 2010); o bien un estudio anterior como el de Fernando Zamora Águila, Filosofía de la imagen (México: Universidad Nacional Autónoma de México, 2007). 
DOI: http://dx.doi.org/10.22201/iie.18703062e.2014.105.2532

254

TANIA VANESSA ALVAREZ PORTUGAL

acción en culturas y geografías distintas, ${ }^{83}$ traería un enriquecimiento en el modo de percibirlas y pensarlas. De igual manera debería de suceder a futuro en diversas regiones como aquellas situadas en otros continentes donde el fenómeno de la imagen pueda ser observado desde parámetros no necesariamente procedentes de la cultura occidental. \$

83. Como por ejemplo los textos en el XXXVI Coloquio Internacional de Historia del Arte. Los estatutos de la imagen: creación, manifestación y percepción, eds. Linda Báez y Emilie Carreón (México: Universidad Nacional Autónoma de México-Instituto de Investigaciones Estéticas, 2014). 